Published in final edited form as:

Gastroenterol Clin North Am. 2016 December ; 45(4): 639-652. doi:10.1016/j.gtc.2016.07.003.

\title{
Non-alcoholic fatty liver disease: Pathophysiology and management
}

\author{
Rotonya M. Carr, MD, Amanke Oranu, MD, and Vandana Khungar, MD, MSc \\ University of Pennsylvania, Division of Gastroenterology and Hepatology
}

\section{Abstract/Summary}

NAFLD is an important cause of morbidity and mortality worldwide both because of cardiovascular, hepatic and oncologic sequelae as well as because it is rapidly becoming the leading cause of end stage liver disease and liver transplant. With a prevalence of $30 \%$ in the US, it has reached epidemic proportions. While the metabolic syndrome is a common risk factor, there are differences among racial and ethnic groups, suggesting the complex interaction between hormonal, nutritional and genetic factors at play in disease pathogenesis. The clinical syndrome of NAFLD spans from bland steatosis to steatohepatitis which can progress to fibrosis and cirrhosis. The pathogenesis including roles of hormones, nutritional and intestinal dysbiosis, insulin resistance, lipotoxicity, and hepatic inflammation, and genes are examined. Non-invasive testing and liver biopsy indications are reviewed. Approved and investigational therapies for NAFLD and NASH are outlined in this review of a disease that is currently an area of great interest to the hepatology community.

\section{Keywords}

Non-alcoholic fatty liver disease; NASH; obesity; hepatic steatosis; NASH therapeutics; lipid droplet; perilipins

\section{INTRODUCTION}

Non-alcoholic fatty liver disease (NAFLD) is a clinical diagnosis that includes the presence of $5 \%$ or more hepatic steatosis as determined by liver imaging or biopsy in the absence of secondary causes of hepatic fat accumulation (Table 1). NAFLD spans the spectrum of simple steatosis or non-alcoholic fatty liver (NAFL) to non-alcoholic steatohepatitis (NASH) which is defined histologically as hepatic steatosis, hepatic inflammation, and hepatocellular ballooning with or without fibrosis. NASH can progress to cirrhosis and hepatocellular carcinoma. ${ }^{1}$

Corresponding author: Rotonya M. Carr, 421 Curie Boulevard, 907 Biomedical Research Building, Rotonya.Carr@uphs.upenn.edu, 215-573-3933.

Publisher's Disclaimer: This is a PDF file of an unedited manuscript that has been accepted for publication. As a service to our customers we are providing this early version of the manuscript. The manuscript will undergo copyediting, typesetting, and review of the resulting proof before it is published in its final citable form. Please note that during the production process errors may be discovered which could affect the content, and all legal disclaimers that apply to the journal pertain. 
Current estimates are that NAFLD affects $30 \%$ of the United States (US) population; $32 \%$ of the Middle East population; 30\% of the South American population; 27\% of Asian populations (highest in East Asians); $24 \%$ of the European population; and 13\% of the African population. ${ }^{2-4}$ In the US, men are disproportionately affected. ${ }^{5}$ Hispanic Americans have a higher prevalence of NAFLD compared with Caucasians; while African-Americans have the lowest prevalence among all racial and ethnic groups in the US. ${ }^{6}$ Among the Hispanic population, those of Mexican heritage have the highest prevalence while Dominican Republicans have the lowest prevalence. ${ }^{7,8}$ The etiology of this racial and ethnic disparity is likely multi-factorial and includes contributions from genetic, behavioral and socio-economic factors. ${ }^{9}$

NAFLD prevalence parallels that of the obesity epidemic and in the US is expected to become the leading cause of end stage liver disease by $2020 .{ }^{10}$ Like patients who suffer from obesity, patients with NAFLD have a higher risk of diabetes, cardiovascular disease and carcinoma. ${ }^{11}$ Indeed, the metabolic syndrome (defined as the presence of three or more of fasting glucose $\geq 100 \mathrm{mg} / \mathrm{dL}$, blood pressure $\geq 130 / 85$, triglycerides $\geq 150 \mathrm{mg} / \mathrm{dL}$, HDL$\mathrm{C}<40 \mathrm{mg} / \mathrm{dL}$ in men or $<50 \mathrm{mg} / \mathrm{dL}$ in women, waist circumference $>40$ inches in men or 35 inches in women ${ }^{12}$ (and if Asian American $>35$ in men or $>32$ in women ${ }^{13}$ )) is common in NAFLD patients. Consequently, NAFLD is often considered its hepatic manifestation ${ }^{14}$ (although this has recently been challenged). ${ }^{15}$

\section{PATHOGENESIS}

NAFLD is a metabolic disorder, and its pathogenesis involves the complex interaction among hormonal, nutritional and genetic factors (Figure 1).

\section{Role of hormones}

The majority of patients with NAFLD suffer from obesity resulting from an imbalance between high energy intake (overnutrition) and energy expenditure. Overnutrition of both high fat foods and sugars has been linked with activating opioid and dopamine receptors in the nucleus accumbens, ${ }^{16,17}$ an area of the brain responsible for the development of cravings. In addition, the macronutrient fructose increases cerebral blood flow to areas of the brain responsible for motivation and reward, failing to reduce satiety when compared with glucose. ${ }^{18}$ Although these pathways have not been examined specifically in NAFLD, it is conceivable that they contribute to obesity in NAFLD patients as well. Concomitant with the activation of reward centers in response to certain macronutrients is the systemic reduction of gut-derived hormones that promote satiety (eg. glucagon-like peptide 1 (GLP-1)) ${ }^{18,19}$ and increase of gut-derived hormones that stimulate hunger (eg. ghrelin). ${ }^{19}$ These changes are associated with an increase in circulating triglyceride levels ${ }^{19}$ and thus are implicated in NAFLD pathogenesis.

In addition to gut-derived hormones, the adipose-derived hormones leptin and adiponectin are suspected to play a role in NAFLD pathogenesis. Leptin primarily acts centrally to reduce food intake and increase energy expenditure. ${ }^{20}$ Adiponectin increases hepatic insulin sensitivity and reduces body fat. ${ }^{21}$ Leptin levels are elevated in NAFLD patients suggesting 
a possible contribution of leptin resistance ${ }^{22}$; while adiponectin levels are low and independently predict risk of NASH in obese patients. ${ }^{23}$

The systemic effects of hormones on both lipid and glucose homeostasis have inspired clinical studies investigating their efficacy in NASH patients. For example, NASH resolved in $39 \%$ of patients who received the GLP1 agonist liraglutide compared with $9 \%$ of patients who received placebo. Liraglutide also reduced fibrosis progression ${ }^{24}$ demonstrating that hormones may be exploited to influence NAFLD risk and severity.

\section{Role of nutrition and intestinal dysbiosis}

One common link among the aforementioned hormones is their regulation by nutritional status. However, because of the inherent challenges of human nutrition studies, the degree to which specific macronutrients increase NAFLD susceptibility is unknown. High saturated fat, low fiber and carbohydrate-rich diets have all been associated with NAFLD risk, ${ }^{25-28}$ but little direct evidence exists in humans. Data from pre-clinical studies demonstrate that diets high in sucrose and fructose are steatogenic, perhaps through their promotion of intestinal dysbiosis or dysregulation of key lipid metabolic pathways and hormones. ${ }^{29}$ In support of these data are studies demonstrating that high fructose $\operatorname{diet}^{30}$ and high soda intake (and therefore consumption of high fructose corn syrup) ${ }^{31}$ increase risk of NAFLD in humans. Such studies, however, are based on dietary intake surveys and are unable to make direct connections between nutrient intake and NAFLD.

Microbiota are primary nutrient sensors within the gastrointestinal tract, and diet modulates gut bacterial composition in NAFLD patients. ${ }^{32}$ Emerging evidence demonstrates that NASH patients have disrupted gut epithelial tight junctions through which bacteria gain access to the systemic circulation and release inflammatory cytokines to promote hepatic steatosis and inflammation. ${ }^{33,34}$ Investigations regarding how specific macronutrients promote these disruptions are needed to inform dietary recommendations for NAFLD patients.

\section{Role of insulin resistance, lipotoxicity, and hepatic inflammation}

Both hyperinsulinemia and insulin resistance are central to NAFLD pathophysiology. ${ }^{35}$ Under normal conditions, pancreatic beta cells secrete insulin primarily in response to circulating glucose levels. Insulin acts on several metabolic tissues, including adipose tissue to promote esterification of fatty acids and storage into lipid droplets while inhibiting the opposing process of lipolysis. In hepatocytes, insulin has three primary actions: to promote glycogen storage, inhibit gluconeogenesis and activate key regulators of de novo lipogenesis. In NAFLD patients, the development of insulin resistance results in 1) increased adipocyte lipolysis and high circulating free fatty acids available for subsequent hepatic uptake, 2) reduced hepatic glycogen storage and 3) and increased gluconeogenesis. Perhaps in response to systemic insulin resistance (or preceding the development of insulin resistance ${ }^{36}$ ), hyperinsulinemia develops which augments hepatic de novo lipogenesis pathways. The net effect is increased intra-hepatic lipid accumulation (steatosis) and accentuated triglyceride secretion in the form of very-low density lipoprotein. The increased lipid load circulates to 
adipose tissue, thus compounding the already reduced ability of adipocytes to store these lipids in lipid droplets.

In hepatocytes, the inability to accommodate neutral lipids within lipid droplets exposes cells to lipotoxic bioactive lipids. Lipotoxicity further impairs insulin signaling, causes oxidative damage, and promotes inflammation and fibrosis through a number of mechanisms. ${ }^{37}$ These downstream effects are thought to be responsible for progression from NAFL to NASH and development of fibrosis and hepatocellular carcinoma in NAFLD patients.

\section{Role of Genes}

Perhaps the most compelling evidence for genetic contributions to NAFLD is the observation by Makkonen, et al. that among monozygotic Finnish twins, liver fat and serum alanine aminotransferase (ALT) vary independently of obesity and alcohol use ${ }^{38}$. These early genetic studies have been bolstered by results from present day genome-wide association studies (GWAS) which have implicated several genetic polymorphisms associated with NAFLD risk and severity (Table 2). The earliest and most widely reported association is the patatin-like phospholipase domain-containing 3 (PNPLA3) gene, a protein with both triacylglyerol lipase and acylglycerol transacylase activity. ${ }^{39,}, 40$ The single nucleotide polymorphism (SNP) I148M (isoleucine to methione at position 148) of PNPLA3 has been associated with both NAFLD risk and severity in adults ${ }^{41-43}$ and children ${ }^{44}$. This so-called "G" allele is found most commonly among Hispanics and least frequently among African-Americans ${ }^{42}$, the demographic groups with the highest and lowest risk of NAFLD in the US population, respectively. Among Hispanics, Mexican-Americans have the highest prevalence of the "G" allele. ${ }^{45}$ Conversely, a serine to isoleucine change in codon 453 appears to be protective of hepatic steatosis and is more commonly seen in AfricanAmericans. ${ }^{42}$ Whether PNPLA3 per se is involved pathogenically in NAFLD is still unclear owing partially to inconsistencies in cell culture and in vivo genetic models. ${ }^{46-48}$

GWAS studies have identified several additional loci associated with NAFLD, namely neurocan (NCAN), glucokinase regulator (GCKR), lysophospholipase like 1 (LYPLAL1), transmembrane 6-superfamily member 2 (TM6SF2) and protein phosphatase 1 regulatory subunit 3B (PPP1R3B) ${ }^{45}$, 49. Like PNPLA3 polymorphisms, these genes have differential associations with ethnic groups ${ }^{50}$ and together are estimated to account for as much as $28 \%$ of the variation in hepatic steatosis as measured by CT scan. ${ }^{49}$ A summary of these genes is included in Table 2. The functional significance of all of these genes has not been fully determined in NAFLD patients, thus highlighting some of the challenges inherent in extrapolating GWAS data to clinical care and demonstrating the limitations of using these tools in whole population screens.

\section{DIAGNOSIS AND STAGING}

\section{Non-invasive tests}

Diagnosis of NAFLD is based on a combination of clinical factors and liver imaging. Clinical assessment involves a detailed alcohol consumption history, examination of 
personal and family metabolic risk factors, medication history (including supplements) and serologic testing. A summary of our approach to initial evaluation is outlined in Table 3.

Liver enzymes are not a component of NAFLD diagnostic criteria, as up to $60 \%$ of NAFLD patients with normal ALT can have NASH or advanced fibrosis, and 53\% of NAFLD patients with elevated ALT do not have NASH or advanced fibrosis ${ }^{51,52}$.

Despite using the standard assessments, diagnosis of NAFLD remains challenging in some patients as high serum autoantibodies, high ferritin, and low ceruloplasmin can be seen in the absence of concomitant chronic liver disease. As many as 20\% of NAFLD patients may have abnormal autoantibody titers. ${ }^{53-55}$ Abnormal results of serologic tests in the context of additional clinical features which support alternative diagnoses should be evaluated further and may require liver biopsy.

Clinical history and serologic testing are combined with radiologic findings (ultrasound, CT or MRI) to make the diagnosis of NAFLD in the majority of patients. Notably, most patients diagnosed with NAFLD are initially suspected because of an incidental radiologic finding of hepatic steatosis. The presence of at least $30 \%$ hepatic steatosis is optimal to visualize hepatic steatosis by these common radiology tools ${ }^{56}$ although there is wide inter- and intraobserver variability. ${ }^{57}$ None of the standard radiologic modalities can detect the presence of steatohepatitis or early fibrosis. 57

The inability of standard radiology protocols to detect advanced stages of NAFLD has spurred research in other non-invasive strategies to stage NAFLD severity. Serologic tests and biomarker panels, ultrasound transient elastography (TE), and MRI elastography (MRE) can be used to stage NAFLD. Cytokeratin-18 (CK-18) is a hepatocyte intermediate filament that is cleaved by caspases during apoptosis whose serum levels are elevated in NASH patients. ${ }^{58}$ Although this test discriminates NAFL from NASH, CK-18 is not commercially available in the US, thus limiting its practical use. Unlike discrimination of NASH, several modalities are available for the non-invasive assessment of fibrosis in NAFLD patients. The most validated biomarker panel is the NAFLD Fibrosis Score (NFS) ${ }^{1}$ which calculates probability of advanced fibrosis based on readily available clinical data: age, BMI, AST, ALT, platelets, albumin, and presence or absence of impaired fasting glucose. A low cutoff score -1.455 excludes advanced fibrosis (negative predictive value of $93 \%$ ), while a high cutoff score 0.676 suggests advanced fibrosis (positive predictive value $90 \%$ ). ${ }^{59}$

Both TE and MRE measure liver stiffness. TE performs less well in obese patients with a failure rate of up to $16 \%{ }^{60}$ and overestimates fibrosis in patients with significant steatosis or inflammation. ${ }^{61}$ An extra large (XL) probe for TE was designed for use in overweight and obese patients however median liver stiffness measurements were on average lower with the XL probe compared with the standard M probe. ${ }^{62}$ To date, these differences have not resulted in a new scoring system with use of this probe limiting interpretation of XL probederived results. MRE performs better than TE for fibrosis assessment ${ }^{63}$ but the expense of this technology limits widespread adoption. 


\section{Liver biopsy}

Due to the limitations of non-invasive testing in NAFLD patients, liver biopsy remains the gold standard for NAFLD staging. Nevertheless, the prevalence of NAFLD, relatively low likelihood of progressive disease in the majority of patients, dearth of treatment options, risk of biopsy, and the uncertain cost effectiveness of invasive testing, preclude liver biopsy from being recommended in all patients. Current guidelines limit liver biopsy to those patients who have an uncertain diagnosis or who are likely to have advanced disease based on noninvasive assessment modalities described above. ${ }^{1}$ Consensus guidelines recommend use of a transjugular approach for patients who are morbidly obese with an obscured flank site. To reduce risk of bleeding, guidelines recommend the following: ${ }^{64}$

- $\quad$ Hold anti-platelets from several days to 10 days prior

- $\quad$ Hold warfarin at least 5 days prior

- $\quad$ Hold heparin products 12-24 hours prior

- Weigh above against risk of thrombotic event

Although there is no formal recommendation regarding the use of vitamin E prior to liver biopsy, vitamin $\mathrm{E}$ in high doses does have anticoagulant properties ${ }^{65}$ and consideration may be made to hold this prior to liver biopsy.

The range of NAFLD histology includes simple steatosis, steatohepatitis, fibrosis and cirrhosis. Of these, fibrosis is the histologic feature that best predicts NAFLD mortality. ${ }^{66}$ Steatosis results from hepatocellular accumulation of cytoplasmic macrovesicular lipid droplets that displace the nucleus. Lipid droplets are cores of primarily neutral lipids (triglycerides) surrounded by a single phospholipid membrane. The membrane is comprised of lipid droplet proteins and metabolically active enzymes. The predominant hepatocellular lipid droplet proteins are members of the perilipin family of proteins. Perlipin 2 and Perilipin 3 are expressed in NAFL whereas Perilipin 1 is de novo expressed in steatohepatitis. ${ }^{67-70}$

The recent NASH Clinical Research Network pathologic scoring system is based on the original Brunt histologic criteria but expands the fibrosis stages to delineate pattern of fibrosis. ${ }^{71}$ Even with expert pathology examination, challenges remain with staging NAFLD patients. Because a standard needle biopsy sample approximates only 1/50000 of the mass of the liver, ${ }^{64}$ liver biopsy specimens are highly variable. ${ }^{72}$ This underscores the need for providers to be judicious in recommending liver biopsy for the management of NAFLD patients.

\section{MANAGEMENT}

Mortality from NAFLD is due to cardiometabolic disease (12.7\%), non-HCC malignancy $(8.1 \%)$, and liver disease (including HCC) $(6.9 \%) .{ }^{11}$ Eighteen-year liver-related mortality is greater in NASH compared with non-NASH patients (17.5\% versus $2.7 \%$, respectively). ${ }^{11}$ The risk of mortality from cardiometabolic and oncologic disease in NAFLD patients requires that special attention be paid to both metabolic and cancer risk factors. Namely, assessment and management of obesity, hyperlipidemia (notwithstanding institution of 
statins which improve mortality in NASH cirrhotics ${ }^{66}$ ), insulin resistance and diabetes is recommended for all patients. In addition, patients are advised to undergo standard cancer screening examinations according to their age, gender and family history. In our practice, we additionally co-manage patients with primary care, cardiology, endocrinology, and nutrition (Figure 2).

In addition to surveillance of risk factors for mortality, all patients should be placed on an appropriate dietary and exercise regimen to promote weight loss of at least $5 \%$ for those with NAFL or 7-9\% for those with NASH. Such lifestyle modification improves transaminases and liver histology ${ }^{73}$ and also reverses fibrosis. ${ }^{74}$ In fact, $90 \%$ of patients who achieve $\geq 10 \%$ weight loss have complete NASH resolution. ${ }^{74}$

The finding of advanced fibrosis or cirrhosis on liver biopsy in a NAFLD patient necessitates screening for complications of cirrhosis and referral to hepatology if a referral has not already been made. In addition to standard dietary recommendations, we recommend complete alcohol abstinence for patients with advanced NAFLD. All patients with advanced fibrosis and cirrhosis require both endoscopic variceal screening and radiologic surveillance for hepatocellular carcinoma (HCC) every 6 months. There may be an increased risk of HCC even in the absence of cirrhosis in NAFLD. Among patients with metabolic syndrome and no other etiology of chronic liver disease $65.5 \%$ of patients with HCC had no or mild fibrosis; and patients diagnosed with cryptogenic cirrhosis without apparent metabolic syndrome developed HCC in non-fibrotic livers more commonly than in fibrotic livers (75\% versus $25 \%$ ). ${ }^{75}$ Further studies are warranted to determine the feasibility and utility of earlier HCC screening in NAFLD patients.

\section{Approved pharmacologic therapy and investigational agents}

Only two therapies are currently recommended for use in NASH patients, Pioglitazone and vitamin E. In both diabetic ${ }^{76}$ and non-diabetic patients ${ }^{77}$, treatment with pioglitazone (30$45 \mathrm{mg}$ daily) improves NASH compared with placebo. ${ }^{77}$ Treatment, however, is associated with significant weight gain. Vitamin $\mathrm{E}$ was investigated in the PIVENs trial, a randomized control trial examining the benefit of pioglitazone or vitamin $\mathrm{E}$ versus placebo in nondiabetic NASH patients. Patients treated with $800 \mathrm{IU}$ of vitamin E daily for 96 weeks demonstrated reduced steatosis and inflammation. ${ }^{77}$ The use of vitamin $\mathrm{E}$ is reserved for biopsy-proven NASH in non-diabetic patients.

\section{Investigational therapies}

Over the past several years, there has been a surge in NAFLD therapeutic trials. Among the investigational agents is a new class of farnesoid X receptor (FXR) agonists. FXR agonists regulate both glucose and lipid homeostasis. Obeticholic acid is the first drug in this class under investigation for NASH. ${ }^{78}$ A recent randomized, double-blinded placebo-controlled trial of non-diabetic NASH patients demonstrated improvement in histologic NASH in 45\% of patients who received obeticholic acid versus $21 \%$ of placebo patients. In addition, patients who received obeticholic acid had improvement of fibrosis compared with placebo. ${ }^{79}$ There was a lack of improvement in insulin sensitivity and dyslipidemia that 
developed in patients who took obeticholic acid, and a Phase III trial is currently underway. ${ }^{80}$

The PPARa/ $\delta$ agent elafibrinor has also recently been studied in NASH. Compared with placebo, elafibranor improved liver enzymes and serum lipids. In an intention-to-treat analysis of the primary endpoint, elafibranor failed to resolve NASH; however, using a modified endpoint, elafibranor resolved NASH without fibrosis worsening (20\% versus $11 \%$ ). This medication caused a reversible increase in serum creatinine and, as a result, requires further investigation. ${ }^{81}$

Besides pharmacotherapy, several studies have demonstrated the effectiveness of obesity surgery for NASH demonstrating up to $85 \%$ NASH resolution one year after surgery. ${ }^{82}$ Although there are now several anti-obesity endoscopic procedures under investigation, ${ }^{83}$ none have been evaluated for the primary indication of NASH. However, it is conceivable that there would be improvements in NASH histology if similar weight loss is achieved with these procedures.

Regardless of the modality, the management of NAFLD patients requires interventions that work systemically to integrate hepatic and extra-hepatic signals. Such therapies must incorporate lifestyle changes to impact cardiovascular endpoints and accomplish weight reduction as weight loss of $7-10 \%$ is currently the only therapy that achieves NASH resolution in a majority of patients.

\section{SUMMARY/DISCUSSION}

NAFLD is an important cause of morbidity and mortality worldwide both because of cardiovascular and oncologic sequelae as well as because it is rapidly becoming the leading cause of end stage liver disease and liver transplant. With a prevalence of $30 \%$ in the US it has reached epidemic proportions. While the metabolic syndrome is a common risk factor, there are differences among racial and ethnic groups, suggesting the complex interaction between hormonal, nutritional and genetic factors at play in disease pathogenesis. Furthermore, these biologic factors likely intersect with socioeconomic forces that ultimately influence one's susceptibility to NAFLD and likelihood of progression to advanced stages.

The complexity of NAFLD pathogenesis mirrors that of its management in that successful care of NAFLD patients requires a multi-system, integrated approach. Close attention must be paid to overall metabolic health in addition to hepatic health. Providers should assess and manage risk factors aggressively and estimate risk of fibrosis at presentation and longitudinally. Hepatology referral can be made at any stage but especially at the stage where fibrosis is suspected. The arena of treatment options is an area ripe for innovation as few currently approved treatments exist. Regression of NASH and fibrosis is possible with weight loss, however, we anticipate that adjunctive pharmacologic and non-pharmacologic therapies may be available for the care of NAFLD patients in the future. 


\section{Acknowledgments}

Disclosures and Funding Sources Research support from Intercept (RMC); NIH/NIAAA K08-AA021424, Robert Wood Johnson Foundation, Harold Amos Medical Faculty Development Award, 7158, IDOM DRC Pilot Award P30 DK019525 (RMC); NIH/NIDDK T32 DK007066 (AO). This work was supported in part by NIH P30DK050306 and its core facilities and its pilot grant program.

\section{REFERENCES}

1. Chalasani N, Younossi Z, Lavine JE, Diehl AM, Brunt EM, Cusi K, Charlton M, Sanyal AJ. The diagnosis and management of non-alcoholic fatty liver disease: Practice guideline by the american association for the study of liver diseases, american college of gastroenterology, and the american gastroenterological association. Hepatology. 2012; 55:2005-2023. [PubMed: 22488764]

2. Younossi ZM, Koenig AB, Abdelatif D, Fazel Y, Henry L, Wymer M. Global epidemiology of nonalcoholic fatty liver disease-meta-analytic assessment of prevalence, incidence and outcomes. Hepatology. 2015

3. Vernon G, Baranova A, Younossi ZM. Systematic review: The epidemiology and natural history of non-alcoholic fatty liver disease and non-alcoholic steatohepatitis in adults. Aliment Pharmacol Ther. 2011; 34:274-285. [PubMed: 21623852]

4. Petersen KF, Dufour S, Feng J, Befroy D, Dziura J, Dalla Man C, Cobelli C, Shulman GI. Increased prevalence of insulin resistance and nonalcoholic fatty liver disease in asian-indian men. Proc Natl Acad Sci U S A. 2006; 103:18273-18277. [PubMed: 17114290]

5. Pan JJ, Fallon MB. Gender and racial differences in nonalcoholic fatty liver disease. World J Hepatol. 2014; 6:274-283. [PubMed: 24868321]

6. Browning JD, Szczepaniak LS, Dobbins R, Nuremberg P, Horton JD, Cohen JC, Grundy SM, Hobbs HH. Prevalence of hepatic steatosis in an urban population in the united states: Impact of ethnicity. Hepatology. 2004; 40:1387-1395. [PubMed: 15565570]

7. Fleischman MW, Budoff M, Zeb I, Li D, Foster T. Nafld prevalence differs among hispanic subgroups: The multi-ethnic study of atherosclerosis. World journal of gastroenterology. 2014; 20:4987-4993. [PubMed: 24803810]

8. Kallwitz ER, Daviglus ML, Allison MA, Emory KT, Zhao L, Kuniholm MH, Chen J, Gouskova N, Pirzada A, Talavera GA, Youngblood ME, Cotler SJ. Prevalence of suspected nonalcoholic fatty liver disease in hispanic/latino individuals differs by heritage. Clin Gastroenterol Hepatol. 2015; 13:569-576. [PubMed: 25218670]

9. Saab S, Manne V, Nieto J, Schwimmer JB, Chalasani NP. Nonalcoholic fatty liver disease in latinos. Clin Gastroenterol Hepatol. 2016; 14:5-12. quiz e19-10. [PubMed: 25976180]

10. Charlton MR, Burns JM, Pedersen RA, Watt KD, Heimbach JK, Dierkhising RA. Frequency and outcomes of liver transplantation for nonalcoholic steatohepatitis in the united states. Gastroenterology. 2011; 141:1249-1253. [PubMed: 21726509]

11. Rafiq N, Bai C, Fang Y, Srishord M, McCullough A, Gramlich T, Younossi ZM. Long-term followup of patients with nonalcoholic fatty liver. Clinical gastroenterology and hepatology : the official clinical practice journal of the American Gastroenterological Association. 2009; 7:234-238. [PubMed: 19049831]

12. Grundy SM, Cleeman JI, Daniels SR, Donato KA, Eckel RH, Franklin BA, Gordon DJ, Krauss RM, Savage PJ, Smith SC Jr, Spertus JA, Costa F. Diagnosis and management of the metabolic syndrome: An american heart association/national heart, lung, and blood institute scientific statement. Circulation. 2005; 112:2735-2752. [PubMed: 16157765]

13. Liu J, Grundy SM, Wang W, Smith SC Jr, Vega GL, Wu Z, Zeng Z, Zhao D. Ethnic-specific criteria for the metabolic syndrome: Evidence from china. Diabetes Care. 2006; 29:1414-1416. [PubMed: 16732037]

14. Marchesini G, Bugianesi E, Forlani G, Cerrelli F, Lenzi M, Manini R, Natale S, Vanni E, Villanova N, Melchionda N, Rizzetto M. Nonalcoholic fatty liver, steatohepatitis, and the metabolic syndrome. Hepatology. 2003; 37:917-923. [PubMed: 12668987]

15. Lonardo A, Ballestri S, Marchesini G, Angulo P, Loria P. Nonalcoholic fatty liver disease: A precursor of the metabolic syndrome. Dig Liver Dis. 2015; 47:181-190. [PubMed: 25739820] 
16. Pelchat ML, Johnson A, Chan R, Valdez J, Ragland JD. Images of desire: Food-craving activation during fmri. Neuroimage. 2004; 23:1486-1493. [PubMed: 15589112]

17. Kelley AE, Bakshi VP, Haber SN, Steininger TL, Will MJ, Zhang M. Opioid modulation of taste hedonics within the ventral striatum. Physiol Behav. 2002; 76:365-377. [PubMed: 12117573]

18. Page KA, Chan O, Arora J, Belfort-Deaguiar R, Dzuira J, Roehmholdt B, Cline GW, Naik S, Sinha R, Constable RT, Sherwin RS. Effects of fructose vs glucose on regional cerebral blood flow in brain regions involved with appetite and reward pathways. Jama. 2013; 309:63-70. [PubMed: 23280226]

19. Teff KL, Elliott SS, Tschop M, Kieffer TJ, Rader D, Heiman M, Townsend RR, Keim NL, D'Alessio D, Havel PJ. Dietary fructose reduces circulating insulin and leptin, attenuates postprandial suppression of ghrelin, and increases triglycerides in women. J Clin Endocrinol Metab. 2004; 89:2963-2972. [PubMed: 15181085]

20. Ahima RS, Flier JS. Leptin. Annu Rev Physiol. 2000; 62:413-437. [PubMed: 10845097]

21. Buechler C, Wanninger J, Neumeier M. Adiponectin, a key adipokine in obesity related liver diseases. World journal of gastroenterology. 2011; 17:2801-2811. [PubMed: 21734787]

22. Chitturi S, Farrell G, Frost L, Kriketos A, Lin R, Fung C, Liddle C, Samarasinghe D, George J. Serum leptin in nash correlates with hepatic steatosis but not fibrosis: A manifestation of lipotoxicity? Hepatology. 2002; 36:403-409. [PubMed: 12143049]

23. Targher G, Bertolini L, Rodella S, Zoppini G, Scala L, Zenari L, Falezza G. Associations between plasma adiponectin concentrations and liver histology in patients with nonalcoholic fatty liver disease. Clin Endocrinol (Oxf). 2006; 64:679-683. [PubMed: 16712671]

24. Armstrong MJ, Gaunt P, Aithal GP, Barton D, Hull D, Parker R, Hazlehurst JM, Guo K, Abouda G, Aldersley MA, Stocken D, Gough SC, Tomlinson JW, Brown RM, Hubscher SG, Newsome PN. Liraglutide safety and efficacy in patients with non-alcoholic steatohepatitis (lean): A multicentre, double-blind, randomised, placebo-controlled phase 2 study. Lancet. 2016; 387:679-690. [PubMed: 26608256]

25. Kang H, Greenson JK, Omo JT, Chao C, Peterman D, Anderson L, Foess-Wood L, Sherbondy MA, Conjeevaram HS. Metabolic syndrome is associated with greater histologic severity, higher carbohydrate, and lower fat diet in patients with nafld. Am J Gastroenterol. 2006; 101:2247-2253. [PubMed: 17032189]

26. Musso G, Gambino R, De Michieli F, Cassader M, Rizzetto M, Durazzo M, Faga E, Silli B, Pagano G. Dietary habits and their relations to insulin resistance and postprandial lipemia in nonalcoholic steatohepatitis. Hepatology. 2003; 37:909-916. [PubMed: 12668986]

27. Lai HS, Lin WH, Chen PR, Wu HC, Lee PH, Chen WJ. Effects of a high-fiber diet on hepatocyte apoptosis and liver regeneration after partial hepatectomy in rats with fatty liver. JPEN J Parenter Enteral Nutr. 2005; 29:401-407. [PubMed: 16224031]

28. Sullivan S. Implications of diet on nonalcoholic fatty liver disease. Curr Opin Gastroenterol. 2010; 26:160-164. [PubMed: 20010099]

29. Festi D, Schiumerini R, Eusebi LH, Marasco G, Taddia M, Colecchia A. Gut microbiota and metabolic syndrome. World journal of gastroenterology. 2014; 20:16079-16094. [PubMed: 25473159]

30. Ouyang X, Cirillo P, Sautin Y, McCall S, Bruchette JL, Diehl AM, Johnson RJ, Abdelmalek MF. Fructose consumption as a risk factor for non-alcoholic fatty liver disease. J Hepatol. 2008; 48:993-999. [PubMed: 18395287]

31. Abid A, Taha O, Nseir W, Farah R, Grosovski M, Assy N. Soft drink consumption is associated with fatty liver disease independent of metabolic syndrome. J Hepatol. 2009; 51:918-924. [PubMed: 19765850]

32. Mouzaki M, Comelli EM, Arendt BM, Bonengel J, Fung SK, Fischer SE, McGilvray ID, Allard JP. Intestinal microbiota in patients with nonalcoholic fatty liver disease. Hepatology. 2013; 58:120127. [PubMed: 23401313]

33. Miele L, Valenza V, La Torre G, Montalto M, Cammarota G, Ricci R, Masciana R, Forgione A, Gabrieli ML, Perotti G, Vecchio FM, Rapaccini G, Gasbarrini G, Day CP, Grieco A. Increased intestinal permeability and tight junction alterations in nonalcoholic fatty liver disease. Hepatology. 2009; 49:1877-1887. [PubMed: 19291785] 
34. Giorgio V, Miele L, Principessa L, Ferretti F, Villa MP, Negro V, Grieco A, Alisi A, Nobili V. Intestinal permeability is increased in children with non-alcoholic fatty liver disease, and correlates with liver disease severity. Dig Liver Dis. 2014; 46:556-560. [PubMed: 24631029]

35. Fu Z, Gilbert ER, Liu D. Regulation of insulin synthesis and secretion and pancreatic beta-cell dysfunction in diabetes. Curr Diabetes Rev. 2013; 9:25-53. [PubMed: 22974359]

36. McGarry JD. What if minkowski had been ageusic? An alternative angle on diabetes. Science. 1992; 258:766-770. [PubMed: 1439783]

37. Gao B, Tsukamoto H. Inflammation in alcoholic and nonalcoholic fatty liver disease: Friend or foe? Gastroenterology. 2016; 150:1704-1709. [PubMed: 26826669]

38. Makkonen J, Pietilainen KH, Rissanen A, Kaprio J, Yki-Jarvinen H. Genetic factors contribute to variation in serum alanine aminotransferase activity independent of obesity and alcohol: A study in monozygotic and dizygotic twins. J Hepatol. 2009; 50:1035-1042. [PubMed: 19303161]

39. Jenkins CM, Mancuso DJ, Yan W, Sims HF, Gibson B, Gross RW. Identification, cloning, expression, and purification of three novel human calcium-independent phospholipase a2 family members possessing triacylglycerol lipase and acylglycerol transacylase activities. J Biol Chem. 2004; 279:48968-48975. [PubMed: 15364929]

40. He S, McPhaul C, Li JZ, Garuti R, Kinch L, Grishin NV, Cohen JC, Hobbs HH. A sequence variation (i148m) in pnpla3 associated with nonalcoholic fatty liver disease disrupts triglyceride hydrolysis. J Biol Chem. 2010; 285:6706-6715. [PubMed: 20034933]

41. Speliotes EK, Butler JL, Palmer CD, Voight BF, Hirschhorn JN. Pnpla3 variants specifically confer increased risk for histologic nonalcoholic fatty liver disease but not metabolic disease. Hepatology. 2010; 52:904-912. [PubMed: 20648472]

42. Romeo S, Kozlitina J, Xing C, Pertsemlidis A, Cox D, Pennacchio LA, Boerwinkle E, Cohen JC, Hobbs HH. Genetic variation in pnpla3 confers susceptibility to nonalcoholic fatty liver disease. Nat Genet. 2008; 40:1461-1465. [PubMed: 18820647]

43. Sookoian S, Pirola CJ. Meta-analysis of the influence of i148m variant of patatin-like phospholipase domain containing 3 gene (pnpla3) on the susceptibility and histological severity of nonalcoholic fatty liver disease. Hepatology. 2011; 53:1883-1894. [PubMed: 21381068]

44. Santoro N, Kursawe R, D'Adamo E, Dykas DJ, Zhang CK, Bale AE, Cali AM, Narayan D, Shaw MM, Pierpont B, Savoye M, Lartaud D, Eldrich S, Cushman SW, Zhao H, Shulman GI, Caprio S. A common variant in the patatin-like phospholipase 3 gene (pnpla3) is associated with fatty liver disease in obese children and adolescents. Hepatology. 2010; 52:1281-1290. [PubMed: 20803499]

45. Hernaez R, McLean J, Lazo M, Brancati FL, Hirschhorn JN, Borecki IB, Harris TB, Nguyen T, Kamel IR, Bonekamp S, Eberhardt MS, Clark JM, Kao WH, Speliotes EK. Association between variants in or near pnpla3, gckr, and ppp1r3b with ultrasound-defined steatosis based on data from the third national health and nutrition examination survey. Clinical gastroenterology and hepatology : the official clinical practice journal of the American Gastroenterological Association. 2013; 11:1183-1190. e1182. [PubMed: 23416328]

46. Basantani MK, Sitnick MT, Cai L, Brenner DS, Gardner NP, Li JZ, Schoiswohl G, Yang K, Kumari M, Gross RW, Zechner R, Kershaw EE. Pnpla3/adiponutrin deficiency in mice does not contribute to fatty liver disease or metabolic syndrome. J Lipid Res. 2011; 52:318-329. [PubMed: 21068004]

47. Li JZ, Huang Y, Karaman R, Ivanova PT, Brown HA, Roddy T, Castro-Perez J, Cohen JC, Hobbs $\mathrm{HH}$. Chronic overexpression of pnpla3i148m in mouse liver causes hepatic steatosis. J Clin Invest. 2012; 122:4130-4144. [PubMed: 23023705]

48. Smagris E, BasuRay S, Li J, Huang Y, Lai KM, Gromada J, Cohen JC, Hobbs HH. Pnpla3i148m knockin mice accumulate pnpla3 on lipid droplets and develop hepatic steatosis. Hepatology. 2015; 61:108-118. [PubMed: 24917523]

49. Speliotes EK, Yerges-Armstrong LM, Wu J, Hernaez R, Kim LJ, Palmer CD, Gudnason V, Eiriksdottir G, Garcia ME, Launer LJ, Nalls MA, Clark JM, Mitchell BD, Shuldiner AR, Butler JL, Tomas M, Hoffmann U, Hwang SJ, Massaro JM, O'Donnell CJ, Sahani DV, Salomaa V, Schadt EE, Schwartz SM, Siscovick DS, Voight BF, Carr JJ, Feitosa MF, Harris TB, Fox CS, Smith AV, Kao WH, Hirschhorn JN, Borecki IB. Genome-wide association analysis identifies variants associated with nonalcoholic fatty liver disease that have distinct effects on metabolic traits. PLoS Genet. 2011; 7:e1001324. [PubMed: 21423719] 
50. Palmer ND, Musani SK, Yerges-Armstrong LM, Feitosa MF, Bielak LF, Hernaez R, Kahali B, Carr JJ, Harris TB, Jhun MA, Kardia SL, Langefeld CD, Mosley TH Jr, Norris JM, Smith AV, Taylor HA, Wagenknecht LE, Liu J, Borecki IB, Peyser PA, Speliotes EK. Characterization of european ancestry nonalcoholic fatty liver disease-associated variants in individuals of african and hispanic descent. Hepatology. 2013; 58:966-975. [PubMed: 23564467]

51. Fracanzani AL, Valenti L, Bugianesi E, Andreoletti M, Colli A, Vanni E, Bertelli C, Fatta E, Bignamini D, Marchesini G, Fargion S. Risk of severe liver disease in nonalcoholic fatty liver disease with normal aminotransferase levels: A role for insulin resistance and diabetes. Hepatology. 2008; 48:792-798. [PubMed: 18752331]

52. Verma S, Jensen D, Hart J, Mohanty SR. Predictive value of alt levels for non-alcoholic steatohepatitis (nash) and advanced fibrosis in non-alcoholic fatty liver disease (nafld). Liver Int. 2013; 33:1398-1405. [PubMed: 23763360]

53. Adams LA, Lindor KD, Angulo P. The prevalence of autoantibodies and autoimmune hepatitis in patients with nonalcoholic fatty liver disease. Am J Gastroenterol. 2004; 99:1316-1320. [PubMed: 15233671]

54. Cotler SJ, Kanji K, Keshavarzian A, Jensen DM, Jakate S. Prevalence and significance of autoantibodies in patients with non-alcoholic steatohepatitis. J Clin Gastroenterol. 2004; 38:801804. [PubMed: 15365409]

55. Loria P, Lonardo A, Leonardi F, Fontana C, Carulli L, Verrone AM, Borsatti A, Bertolotti M, Cassani F, Bagni A, Muratori P, Ganazzi D, Bianchi FB, Carulli N. Non-organ-specific autoantibodies in nonalcoholic fatty liver disease: Prevalence and correlates. Dig Dis Sci. 2003; 48:2173-2181. [PubMed: 14705824]

56. Lee SS, Park SH, Kim HJ, Kim SY, Kim MY, Kim DY, Suh DJ, Kim KM, Bae MH, Lee JY, Lee SG, Yu ES. Non-invasive assessment of hepatic steatosis: Prospective comparison of the accuracy of imaging examinations. J Hepatol. 2010; 52:579-585. [PubMed: 20185194]

57. Saadeh S, Younossi ZM, Remer EM, Gramlich T, Ong JP, Hurley M, Mullen KD, Cooper JN, Sheridan MJ. The utility of radiological imaging in nonalcoholic fatty liver disease. Gastroenterology. 2002; 123:745-750. [PubMed: 12198701]

58. Feldstein AE, Wieckowska A, Lopez AR, Liu YC, Zein NN, McCullough AJ. Cytokeratin-18 fragment levels as noninvasive biomarkers for nonalcoholic steatohepatitis: A multicenter validation study. Hepatology. 2009; 50:1072-1078. [PubMed: 19585618]

59. Angulo P, Hui JM, Marchesini G, Bugianesi E, George J, Farrell GC, Enders F, Saksena S, Burt AD, Bida JP, Lindor K, Sanderson SO, Lenzi M, Adams LA, Kench J, Therneau TM, Day CP. The nafld fibrosis score: A noninvasive system that identifies liver fibrosis in patients with nafld. Hepatology. 2007; 45:846-854. [PubMed: 17393509]

60. Castera L, Foucher J, Bernard PH, Carvalho F, Allaix D, Merrouche W, Couzigou P, de Ledinghen V. Pitfalls of liver stiffness measurement: A 5-year prospective study of 13,369 examinations. Hepatology. 2010; 51:828-835. [PubMed: 20063276]

61. Rinaldi LR L, Guerrera B, et al. Hepatic steatosis and necro-inflammatory activity overestimate liver stiffness by transient elastography in staging liver fibrosis in chronic hepatitis c. Journal of Hepatitis Research. 2014; 1:1012.

62. Myers RP, Pomier-Layrargues G, Kirsch R, Pollett A, Duarte-Rojo A, Wong D, Beaton M, Levstik M, Crotty P, Elkashab M. Feasibility and diagnostic performance of the fibroscan xl probe for liver stiffness measurement in overweight and obese patients. Hepatology. 2012; 55:199-208. [PubMed: 21898479]

63. Imajo K, Kessoku T, Honda Y, Tomeno W, Ogawa Y, Mawatari H, Fujita K, Yoneda M, Taguri M, Hyogo H, Sumida Y, Ono M, Eguchi Y, Inoue T, Yamanaka T, Wada K, Saito S, Nakajima A. Magnetic resonance imaging more accurately classifies steatosis and fibrosis in patients with nonalcoholic fatty liver disease than transient elastography. Gastroenterology. 2016; 150:626-637. e627. [PubMed: 26677985]

64. Rockey DC, Caldwell SH, Goodman ZD, Nelson RC, Smith AD. Liver biopsy. Hepatology. 2009; 49:1017-1044. [PubMed: 19243014]

65. Booth SL, Golly I, Sacheck JM, Roubenoff R, Dallal GE, Hamada K, Blumberg JB. Effect of vitamin e supplementation on vitamin $\mathrm{k}$ status in adults with normal coagulation status. Am J Clin Nutr. 2004; 80:143-148. [PubMed: 15213041] 
66. Angulo P, Kleiner DE, Dam-Larsen S, Adams LA, Bjornsson ES, Charatcharoenwitthaya P, Mills PR, Keach JC, Lafferty HD, Stahler A, Haflidadottir S, Bendtsen F. Liver fibrosis, but no other histologic features, is associated with long-term outcomes of patients with nonalcoholic fatty liver disease. Gastroenterology. 2015; 149:389-397. e310. [PubMed: 25935633]

67. Carr RM, Ahima RS. Pathophysiology of lipid droplet proteins in liver diseases. Exp Cell Res. 2015

68. Straub BK, Gyoengyoesi B, Koenig M, Hashani M, Pawella LM, Herpel E, Mueller W, MacherGoeppinger S, Heid H, Schirmacher P. Adipophilin/perilipin-2 as a lipid droplet-specific marker for metabolically active cells and diseases associated with metabolic dysregulation. Histopathology. 2013; 62:617-631. [PubMed: 23347084]

69. Straub BK, Stoeffel P, Heid H, Zimbelmann R, Schirmacher P. Differential pattern of lipid dropletassociated proteins and de novo perilipin expression in hepatocyte steatogenesis. Hepatology. 2008; 47:1936-1946. [PubMed: 18393390]

70. Carr RM, Patel RT, Rao V, Dhir R, Graham MJ, Crooke RM, Ahima RS. Reduction of tip47 improves hepatic steatosis and glucose homeostasis in mice. Am J Physiol Regul Integr Comp Physiol. 2012; 302:R996-R1003. [PubMed: 22378776]

71. Kleiner DE, Brunt EM, Van Natta M, Behling C, Contos MJ, Cummings OW, Ferrell LD, Liu YC, Torbenson MS, Unalp-Arida A, Yeh M, McCullough AJ, Sanyal AJ. Design and validation of a histological scoring system for nonalcoholic fatty liver disease. Hepatology. 2005; 41:1313-1321. [PubMed: 15915461]

72. Ratziu V, Charlotte F, Heurtier A, Gombert S, Giral P, Bruckert E, Grimaldi A, Capron F, Poynard T. Sampling variability of liver biopsy in nonalcoholic fatty liver disease. Gastroenterology. 2005; 128:1898-1906. [PubMed: 15940625]

73. Promrat K, Kleiner DE, Niemeier HM, Jackvony E, Kearns M, Wands JR, Fava JL, Wing RR. Randomized controlled trial testing the effects of weight loss on nonalcoholic steatohepatitis. Hepatology. 2010; 51:121-129. [PubMed: 19827166]

74. Vilar-Gomez E, Martinez-Perez Y, Calzadilla-Bertot L, Torres-Gonzalez A, Gra-Oramas B, Gonzalez-Fabian L, Friedman SL, Diago M, Romero-Gomez M. Weight loss through lifestyle modification significantly reduces features of nonalcoholic steatohepatitis. Gastroenterology. 2015; 149:367-378. e365. quiz e314-365. [PubMed: 25865049]

75. Paradis V, Zalinski S, Chelbi E, Guedj N, Degos F, Vilgrain V, Bedossa P, Belghiti J. Hepatocellular carcinomas in patients with metabolic syndrome often develop without significant liver fibrosis: A pathological analysis. Hepatology. 2009; 49:851-859. [PubMed: 19115377]

76. Belfort R, Harrison SA, Brown K, Darland C, Finch J, Hardies J, Balas B, Gastaldelli A, Tio F, Pulcini J, Berria R, Ma JZ, Dwivedi S, Havranek R, Fincke C, DeFronzo R, Bannayan GA, Schenker S, Cusi K. A placebo-controlled trial of pioglitazone in subjects with nonalcoholic steatohepatitis. N Engl J Med. 2006; 355:2297-2307. [PubMed: 17135584]

77. Chalasani NP, Sanyal AJ, Kowdley KV, Robuck PR, Hoofnagle J, Kleiner DE, Unalp A, Tonascia J. Pioglitazone versus vitamin e versus placebo for the treatment of non-diabetic patients with nonalcoholic steatohepatitis: Pivens trial design. Contemp Clin Trials. 2009; 30:88-96. [PubMed: 18804555]

78. Carr RM, Reid AE. Fxr agonists as therapeutic agents for non-alcoholic fatty liver disease. Curr Atheroscler Rep. 2015; 17:500. [PubMed: 25690590]

79. Neuschwander-Tetri BA, Loomba R, Sanyal AJ, Lavine JE, Van Natta ML, Abdelmalek MF, Chalasani N, Dasarathy S, Diehl AM, Hameed B, Kowdley KV, McCullough A, Terrault N, Clark JM, Tonascia J, Brunt EM, Kleiner DE, Doo E. Farnesoid x nuclear receptor ligand obeticholic acid for non-cirrhotic, non-alcoholic steatohepatitis (flint): A multicentre, randomised, placebocontrolled trial. Lancet. 2014

80. Clinical trials.Gov. 2016.

81. Ratziu V, Harrison SA, Francque S, Bedossa P, Lehert P, Serfaty L, Romero-Gomez M, Boursier J, Abdelmalek M, Caldwell S, Drenth J, Anstee QM, Hum D, Hanf R, Roudot A, Megnien S, Staels B, Sanyal A. Elafibranor, an agonist of the peroxisome proliferator-activated receptor-alpha and delta, induces resolution of nonalcoholic steatohepatitis without fibrosis worsening. Gastroenterology. 2016; 150:1147-1159. e1145. [PubMed: 26874076] 
82. Lassailly G, Caiazzo R, Buob D, Pigeyre M, Verkindt H, Labreuche J, Raverdy V, Leteurtre E, Dharancy S, Louvet A, Romon M, Duhamel A, Pattou F, Mathurin P. Bariatric surgery reduces features of nonalcoholic steatohepatitis in morbidly obese patients. Gastroenterology. 2015; 149:379-388. quiz e315-376. [PubMed: 25917783]

83. Abu Dayyeh BK, Edmundowicz SA, Jonnalagadda S, Kumar N, Larsen M, Sullivan S, Thompson CC, Banerjee S. Endoscopic bariatric therapies. Gastrointest Endosc. 2015; 81:1073-1086. [PubMed: 25828245]

84. Gorden A, Yang R, Yerges-Armstrong LM, Ryan KA, Speliotes E, Borecki IB, Harris TB, Chu X, Wood GC, Still CD, Shuldiner AR, Gerhard GS. Genetic variation at ncan locus is associated with inflammation and fibrosis in non-alcoholic fatty liver disease in morbid obesity. Hum Hered. 2013; 75:34-43. [PubMed: 23594525]

85. Sookoian S, Pirola CJ. Meta-analysis of the influence of tm6sf2 e167k variant on plasma concentration of aminotransferases across different populations and diverse liver phenotypes. Sci Rep. 2016; 6:27718. [PubMed: 27278285] 


\section{Key Points}

- $\quad$ Non-alcoholic fatty liver disease (NAFLD) is a systemic disease

- $\quad$ NAFLD pathogenesis involves hormonal, nutritional and genetic factors

- $\quad$ NAFLD mortality is due to cardiovascular disease, cancer and hepatic disease

- $\quad$ Patients with NAFLD should be risk stratified at diagnosis and longitudinally for the presence and degree of fibrosis and referred if advanced disease is suspected

- $\quad$ The cornerstone of NAFLD management is 7-9\% weight loss and management of cardiovascular, oncologic, and hepatic risk factors. 


\section{NAFLD}

Hepatic insulin resistance

(个gluconeogenesis) Exaggerated lipogenesis Inflammation
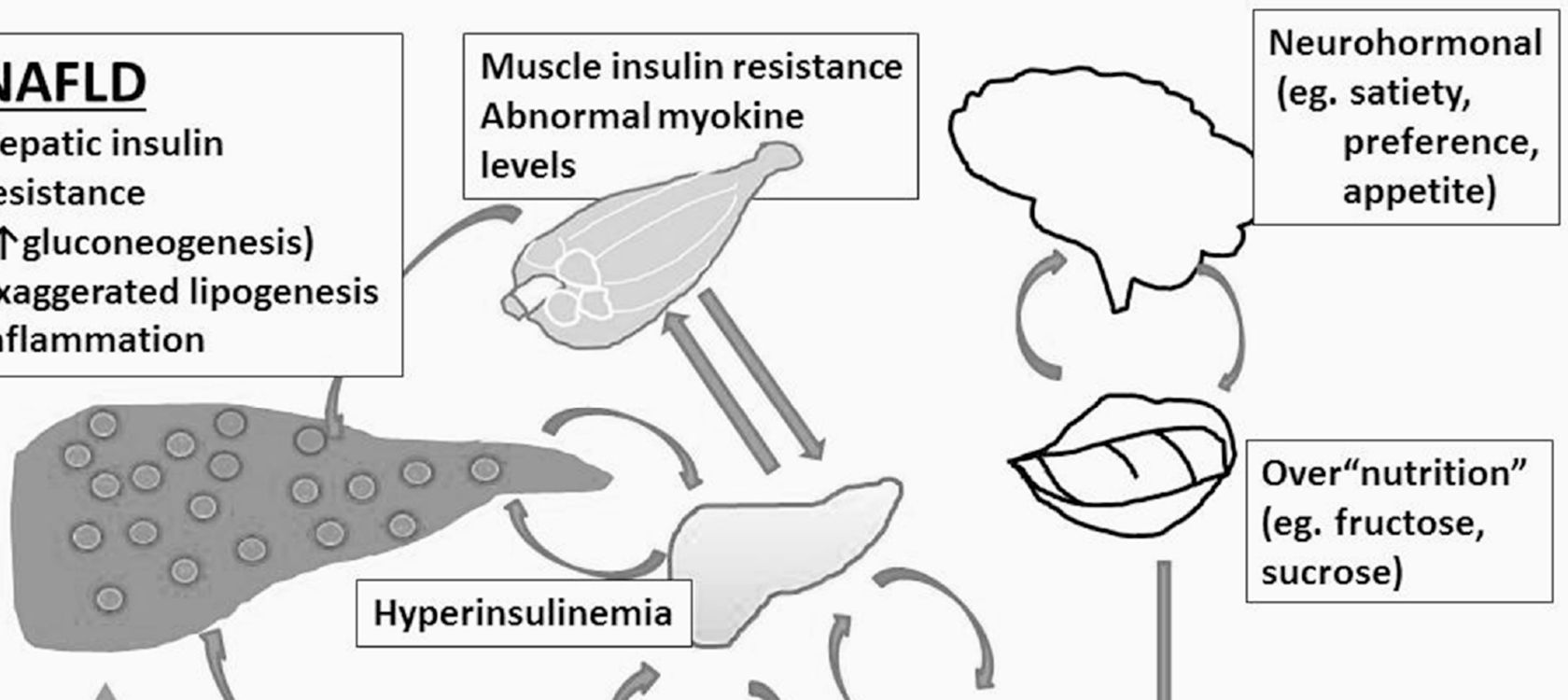

Adipose tissue insulin resistance $\rightarrow$ lipolysis $\rightarrow$ FFA Inflammation Abnormal adipokine levels

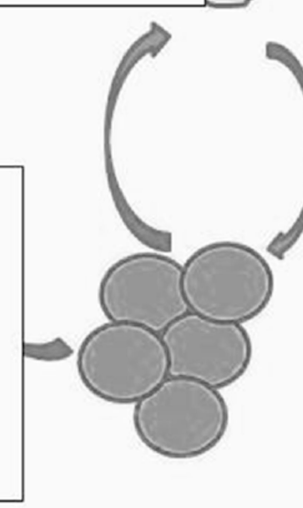

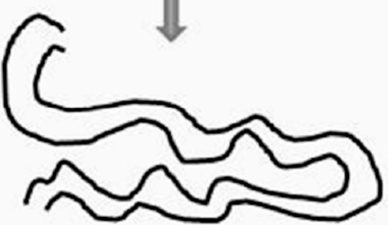

"Leaky gut" Dysbiosis $\downarrow$ GLP-1 Inflammatory mediators (eg. TNF $\alpha$ )

Figure 1.

Pathogenesis of NAFLD. 


\section{CV}

- Glycemic control

- Weight loss

- Lipid

lowering

- Collaborate with

cardiology, endocrin.

\section{Oncologic}

- Glycemic control

- Weight loss

- Assess cancer risk

- Offer routine screening

\section{Hepatic}

- Glycemic control

- Weight loss

- Minimize/ avoid alcohol

- +/- Rx

- Variceal and HCC screening (if advanced disease)

Figure 2.

Strategies to reduce cardiovascular, oncologic and hepatic mortality in NAFLD patients. $\mathrm{Rx}=$ pharmacologic 


\section{Table 1}

\section{Known causes of secondary hepatic steatosis}

\begin{tabular}{|l|l|}
\hline Macrovesicular steatosis & Microvesicular steatosis \\
\hline Excessive alcohol consumption & Reye's syndrome \\
\hline Viral infection- Hepatitis C & Viral infection- Delta hepatitis \\
\hline Wilson's disease & HELLP syndrome \\
\hline Autoimmune hepatitis & Acute fatty liver of pregnancy \\
\hline Parenteral nutrition & $\begin{array}{l}\text { Medications (eg. valproate, tetracycline, } \\
\text { anti-retroviral) }\end{array}$ \\
\hline $\begin{array}{l}\text { Medications (eg. amiodarone, } \\
\text { methotrexate, tamoxifen, corticosteroids, } \\
\text { anti-retrovirals) }\end{array}$ & $\begin{array}{l}\text { Genetic anomalies and inborn errors of } \\
\text { metabolism * }\end{array}$ \\
\hline Starvation - Kwashiorkor & Jamaican vomiting sickness \\
\hline Lipodystrophy & \\
\hline Abetalipoproteinemia & \\
\hline
\end{tabular}

(Lecithin-cholesterol acyltransferase [LCAT] deficiency, urea cycle defects, cholesterol ester storage diseases, defects of fatty acid beta oxidation, lysosomal acid lipase deficiency and Alpers syndrome) 
Table 2

Genetic polymorphisms associated with NAFLD

\begin{tabular}{|c|c|c|}
\hline $\begin{array}{l}\text { Gene } \\
\text { polymorphism }\end{array}$ & Function of gene & NAFLD association \\
\hline $\begin{array}{l}\text { Patatin-like } \\
\text { phospholipase } \\
\text { domain-containing } \\
\text { 3 (PNPLA3) } \\
\text { (I148M) }\end{array}$ & $\begin{array}{l}\text { Triacylglyerol lipase, } \\
\text { acylglycerol } \\
\text { transacylase }\end{array}$ & $\begin{array}{l}\text { Increases NAFLD risk and severity; } \\
\text { highest prevalence in Hispanic- } \\
\text { Americans (highest in Mexican- } \\
\text { Americans) }{ }^{42,45,49,50}\end{array}$ \\
\hline PNPLA3 (S453I) & $\begin{array}{l}\text { Triacylglyerol lipase, } \\
\text { acylglycerol } \\
\text { transacylase }\end{array}$ & $\begin{array}{l}\text { Reduces NAFLD risk and severity; } \\
\text { highest prevalence in African- } \\
\text { Americans }{ }^{42}\end{array}$ \\
\hline Neurocan (NCAN) & $\begin{array}{l}\text { Cell adhesion } \\
\text { molecule }\end{array}$ & $\begin{array}{l}\text { Hepatic steatosis, liver inflammation } \\
\text { and fibrosis } 45,49,84\end{array}$ \\
\hline $\begin{array}{l}\text { Glucokinase } \\
\text { regulatory protein } \\
\text { (GCKR) }\end{array}$ & Glucokinase inhibitor & Hepatic steatosis, increased $\mathrm{ALT}^{45,49}$ \\
\hline $\begin{array}{l}\text { Transmembrane 6- } \\
\text { superfamily } \\
\text { member } 2 \\
(\mathrm{TM} 6 \mathrm{SF} 2)(\mathrm{E} 167 \mathrm{~K})\end{array}$ & Unknown & $\begin{array}{l}\text { Increased ALT, AST and hepatic fat, } \\
\text { small effect size }{ }^{85}\end{array}$ \\
\hline $\begin{array}{l}\text { Protein } \\
\text { phosphatase 1 } \\
\text { regulatory subunit } \\
\text { 3B (PPP1R3B) }\end{array}$ & $\begin{array}{l}\text { Hepatic glycogen } \\
\text { synthesis }\end{array}$ & Hepatic steatosis ${ }^{45,49,50}$ \\
\hline
\end{tabular}


Table 3

Initial Evaluation of a Patient with Suspected NAFLD

\begin{tabular}{|c|c|c|}
\hline History & Physical Exam & Serology \\
\hline $\begin{array}{l}\text { Patterns of weight loss and weight } \\
\text { gain; anti-obesity interventions }\end{array}$ & $\begin{array}{l}\text { Blood pressure, weight, } \\
\text { height (calculate BMI) }\end{array}$ & $\begin{array}{l}\text { Hepatic and basic metabolic } \\
\text { panel (for creatinine) }\end{array}$ \\
\hline Dietary and exercise patterns & Distribution of obesity & $\mathrm{CBC}$ \\
\hline Alcohol intake & $\begin{array}{l}\text { Stigmata of insulin resistance } \\
\text { (eg. acanthosis nigricans) }\end{array}$ & INR \\
\hline Use of parenteral nutrition & $\begin{array}{l}\text { Stigmata of } \\
\text { hypertriglyceridemia (eg. } \\
\text { xanthomas) }\end{array}$ & Fasting lipids \\
\hline Fertility history, menstrual history & $\begin{array}{l}\text { Stigmata of chronic liver } \\
\text { disease (eg. icterus, jaundice, } \\
\text { ascites, spider angiomata, } \\
\text { palmar erythema) }\end{array}$ & $\begin{array}{l}\text { Fasting glucose, insulin } \\
\text { (calculate HOMA-IR), HbA1C }\end{array}$ \\
\hline Risk factors for viral hepatitis & $\begin{array}{l}\text { Stigmata of primary } \\
\text { endocrine disorder }\end{array}$ & Hepatitis C virus antibody \\
\hline $\begin{array}{l}\text { History of autoimmune diseases or } \\
\text { suggestive symptoms }\end{array}$ & $\begin{array}{l}\text { Stigmata of autoimmune } \\
\text { disease (eg. skin rashes, joint } \\
\text { findings) }\end{array}$ & ANA and iron panel \\
\hline Review of steatogenic medications & & $\begin{array}{l}\text { Other }{ }^{*} \text { (eg. additional } \\
\text { autoantibody titers, } \\
\text { ceruloplasmin, alpha } 1 \\
\text { antitrypsin, lysosomal acid } \\
\text { lipase activity) }\end{array}$ \\
\hline $\begin{array}{l}\text { Family history of liver disease, } \\
\text { obesity, diabetes, hyperlipidemia, } \\
\text { cardiovascular disease, cancer }\end{array}$ & & \\
\hline
\end{tabular}

These tests can be individualized based on patient risk factors 